\title{
Sicana odorifera "Kurugua" from Paraguay, Composition and Antioxidant Potential of Interest for the Food Industry ${ }^{+}$
}

\author{
Coronel Eva, Caballero Silvia, Baez Rocio, Villalba Rocio and Mereles Laura * \\ Departamento de Bioquímica de Alimentos, Facultad de Ciencias Químicas, \\ Universidad Nacional de Asunción, P.O. Box 1055, San Lorenzo, Paraguay; ecoronel@qui.una.com (C.E.); \\ scaballero@qui.una.com (C.S.); rocio.baez15@gmail.com (B.R.); rvillalba@qui.una.com (V.R.) \\ * Correspondence: lauramereles@qui.una.py \\ † Presented at the 2nd International Conference of Ia ValSe-Food Network, Lisbon, Portugal, \\ 21-22 October 2019.
}

Published: 6 August 2020

Summary: The aim of this study was to evaluate the physicochemical characteristics, centesimal composition and antioxidants of the Sicana odorifera pulp and the antioxidant potential of the seeds and fruit peel harvested in a culture of the city of San Lorenzo, Paraguay. These fruits harvested in Paraguay present an antioxidant potential, interesting for food industry, especially in a ripe and semi-ripe state, where the highest content of vitamin $C$ and total phenols was observed, as well as the total antioxidant capacity (ABTS).

Keywords: Sicana odorifera; composition; antioxidants; Curcubitaceae; total phenols; vitamin C

\section{Introduction}

Worldwide, the search for food components as additives with functional properties represents a great demand, where biodiversity and the systematic study of species of interest is fundamental to generating knowledge about potential uses of native fruits, with known medicinal applications described in ethnobotany [1]. This specie is cultivated in several countries in South America and Central America, known as melao de croa, cassabanana, or red melon [2]. In Brazil, the composition of the fruit of the kurugua was recently described [2], however, the phytochemical composition of the fruit pulp has been little explored in Paraguay, despite being described as an autochthonous fruit, which limits its use at an industrial level, mainly due to the ignorance of its nutritional potential and consequently of its potential applications. The fruit of the kurugua is used in juices, jams and preserves, it is used as an infusion in popular wisdom for liver diseases [3], and some species of the same family Cucurbitaceae have known hepatoprotective properties [4]. It is known that antioxidants can contribute to liver protection, and they vary in their concentration and quality with the stage of maturity. The objective of the present work was to evaluate the physicochemical characteristics, centesimal composition and antioxidants of the Sicana odorifera pulp and to evaluate the antioxidant potential in the seeds and fruit peel harvested in a culture in San Lorenzo city, Paraguay.

\section{Materials and Methods}

\subsection{Sampling}

Samples of Sicana odorifera fruits "kurugua" were collected from healthy mature trees (12 years old) from an orchard placed at San Lorenzo, Central Department, Paraguay (GPS -25.3266340 N, 
$-57.4832020 \mathrm{E}$ ). The yearly average sunlight in the cultivation place ranges between 6 and $14 \mathrm{~h}$ per day. The orchard is used as a seedbed of the "Kurugua Poty" foundation, which ensured the traceability of the variety analyzed. Samples were collected for herbarium material for botanical identification by the Botánica Department of the Facultad de Ciencias Químicas of the Universidad Nacional de Asunción. Random sampling from the crop of fruits in three stages of maturity-unripe, semi-ripe, and ripe-was carried out. Fourteen kilograms of fruits were obtained. After the morphological measurements, the pulp was separated from the peel and seeds. The centesimal composition was made in the edible fraction (pulp) of ripe fruit.

\subsection{Physicochemical Characters}

Morphological studies were performed on unripe, semi-ripe and ripe fruits without previous treatment, as described by Mereles and Ferro [5]. The $\mathrm{pH}$, titratable acidity and soluble solids were measured according to AOAC Methods [6]. A potentiometer (Accurate $\mathrm{pH} 900$, Horiba, Kyoto, Japan) at $25{ }^{\circ} \mathrm{C}$ and an analytical balance (AYD HR 120, Bradford, England) were used. All measurements were made in triplicate. All the reagents used were of analytical grade.

\subsection{Chemical Analysis}

Moisture, protein, total carbohydrates, dietary fiber, total mineral content or ash were determined, all according to official AOAC methodologies [6]. To estimate the antioxidant potential of the fruit, the content of total phenols, monomeric anthocyanins, vitamin $\mathrm{C}$ and the total antioxidant capacity were evaluated by the ABTS method. The determination was made using the spectrofluorometric method 967.22 of AOAC [6]. For the measurements, an L-ascorbic acid calibration curve $(2.5-20 \mu \mathrm{g} / \mathrm{mL})$ was used. The results were expressed in $\mathrm{mg}$ of vitamin C per $100 \mathrm{~g}$ of pulp fresh weight. The determination of anthocyanins was carried out by the spectrophotometric method of differential $\mathrm{pH}$, based on the color loss of the monomeric anthocyanins at $\mathrm{pH} 4.5$ and presence of color at $\mathrm{pH} \mathrm{1,} \mathrm{measuring} \mathrm{at} 510$ and $700 \mathrm{~nm}$ [1]. The final concentration of anthocyanins $(\mathrm{mg} / 100 \mathrm{~g})$ was calculated based on the volume of extract and sample fresh weight. It is expressed in cyanidinidine 3-glucoside (MW: 449.2 and $\varepsilon: 26,900$ ). An extraction of $2 \mathrm{~g}$ of lyophilized pulp with methanol:water (60:40) in an ultrasonic bath for $15 \mathrm{~min}$ was performed and subsequent centrifugation (15 min, $\left.10,000 \times g \mathrm{rpm}, 4^{\circ} \mathrm{C}\right)$. After separating the supernatant, a second extraction was carried out with acetone:water (70:30) with the same treatment described. Extractions and measurements were carried out by triplicates. Total phenolic compounds (TPC) were determined by the Folin-Ciocalteau described by Singleton \& Rossi [7], colorimetric method using a calibration curve obtained with gallic acid $(0-120 \mu \mathrm{g} / \mathrm{mL}$ aqueous solution). The mixture was stirred and kept for $30 \mathrm{~min}$ at room temperature in the dark. The absorbance was measured spectrophotometrically at $765 \mathrm{~nm}$ against a blank reagent. For measurements, a gallic acid standard curve (concentration interval 0-120 $\mu \mathrm{g} / \mathrm{mL}$ aqueous solution) was plotted at $765 \mathrm{~nm}$ in the UV-1800 spectrophotometer (Shimadzu, Kyoto, Japan). The results were expressed as mg of gallic acid equivalents (GAE) per $100 \mathrm{~g}$ of pulp (mg of $\mathrm{GAE} / 100 \mathrm{~g}$ ). The antioxidant activity was determined by the TEAC assay using the radical cation ABTS+ • [8] (Re et al. 1999). The ABTS+ stock solution (7 mM) was prepared using ammonium persulphate $\left(\mathrm{NH}_{4}\right)_{2} \mathrm{~S}_{2} \mathrm{O}_{8}$ as the oxidant agent. The working solution of ABTS+• was obtained by diluting the stock solution in ethanol to give an absorption of $0.70 \pm 0.02$ at $\lambda=734 \mathrm{~nm}$. For measurements, a calibration curve with Trolox (0-500 $\mu \mathrm{M}$ aqueous solution) was plotted at $730 \mathrm{~nm}$. The results were expressed as micromoles of Trolox equivalents (TEAC) per gram of pulp fresh weight.

\subsection{Statistical Analysis}

The results were expressed as means \pm standard deviation (SD) from three independent replicates. Data were stored in a spreadsheet, when appropriate, to compare stages of maturity values (unripe, semiripe and ripe) ANOVA and Tukey's post-test were used. Values with $p \leq 0.05$ were 
considered as statistically significant with the assistance of Graph Pad Prism 5.0 software (GraphPad Software, Inc., San Diego, CA, USA) for the calculations.

\section{Results and Discussion}

\subsection{Physicochemical Characters}

The physicochemical characteristics of the whole fruit of S. odorifera were determined in three stages of maturity (Table 1). Variations in weight, diameter and height were observed among unripe fruits compared to semi-ripe and ripe fruits. These results are consistent with those reported by Paula Filho et al. (2015) in S. odorifera harvested in Brazil, for the weight and average diameter of the ripe fruits ( $2510 \mathrm{~g}, 9.72 \mathrm{~cm}$, respectively) [3]; however these authors reported that the fruits studied were longer ( $36.91 \mathrm{~cm}$, approximately).

Regarding soluble solids (SS), significant differences were observed between maturity stages, increasing with it, observing 8.24 Brix in mature state, higher than the one reported (4.15 Brix) in Minas, Brazil [3]. In the composition of the ripe fruit (Table 2), it was observed that it has a low caloric intake with high water content $(88.0 \pm 0.1 \mathrm{~g} / 100 \mathrm{~g})$.

Table 1. Physicochemical characterization of the unripe, semi-ripe and ripe Sicana odorifera fruit pulp.

\begin{tabular}{cccc}
\hline Variables & Unripe & Semi-Ripe & Ripe \\
\hline Weight $(\mathrm{g})$ & $956 \pm 21^{\mathrm{a}}$ & $2355 \pm 12^{\mathrm{b}}$ & $1970 \pm 51^{\mathrm{c}}$ \\
Longitudinal diameter $(\mathrm{cm})$ & $19.76 \pm 3.9^{\mathrm{a}}$ & $28.8 \pm 0.7 \mathrm{~b}$ & $26.9 \pm 1.4^{\mathrm{b}}$ \\
Transverse diameter $(\mathrm{cm})$ & $8.4 \pm 1.1^{\mathrm{a}}$ & $11.2 \pm 0.6^{\mathrm{b}}$ & $10.4 \pm 0.7^{\mathrm{b}}$ \\
Soluble solids $\left({ }^{\circ}\right.$ Brix) & $3.26 \pm 0.05^{\mathrm{a}}$ & $4.8 \pm 0.1^{\mathrm{b}}$ & $8.2 \pm 0.2^{\mathrm{c}}$ \\
${\text { Titratable acidity }(\mathrm{g} \text { of Ac. Citrus / } 100 \mathrm{~g}){ }^{*}}^{*}$ & $0.36 \pm 0.088^{\mathrm{a}}$ & $0.22 \pm 0.02^{\mathrm{b}}$ & $0.24 \pm 0.04^{\mathrm{ab}}$ \\
$\mathrm{pH}^{*}$ & $5.65 \pm 0.02^{\mathrm{a}}$ & $6.37 \pm 0.03^{\mathrm{b}}$ & $6.69 \pm 0.04^{\mathrm{c}}$ \\
\hline
\end{tabular}

The values are means \pm SD. Different letters indicate significant differences between means (ANOVA and Tukey's a posteriori test, $p \leq 0.05) .{ }^{*}$ Determinations made in fresh fruit pulp $(n=3)$.

Table 2. Sicana odorifera ripe pulp composition.

\begin{tabular}{cc}
\hline Parameter & Value in Fresh Weight Pulp \\
\hline Moisture $(\mathrm{g} / 100 \mathrm{~g})$ & $88.0 \pm 0.1$ \\
Ash $(\mathrm{g} / 100 \mathrm{~g})$ & $0.15 \pm 0.00$ \\
Total protein $(\mathrm{g} / 100 \mathrm{~g})$ & $1.07 \pm 0.08$ \\
Total carbohydrate $(\mathrm{g} / 100 \mathrm{~g})$ & $5.55 \pm 0.31$ \\
Dietary fiber $(\mathrm{g} / 100 \mathrm{~g})$ & $2.92 \pm 0.00$ \\
Caloric Value $(\mathrm{Kcal} / 100 \mathrm{~g})$ & $26 \pm 5$ \\
\hline
\end{tabular}

The values are means \pm DS $(n=3)$. Determinations made in fresh fruit pulp.

\subsection{Antioxidants Analysis}

Statistically significant differences were observed in the contents of total phenols between the three maturity stages evaluated (Figure 1), unripe, semi-ripe and ripe $(13.8 \pm 0.8,22.8 \pm 2.2$ and $37.5 \pm$ $4.2 \mathrm{mg}$ of GAE/100 g, respectively). The increase in total phenols as the fruit matures is important from the alimentary point of view, since it is the state in which it is consumed directly, and the health benefits associated with these compounds are expected. These results are also superior to those reported by Contreras-Calderón et al. [9] of fruits of S. odorifera harvested in Colombia (15.7 $\pm 1.1 \mathrm{mg}$ of GAE/100 g) in fresh pulp and Marquez et al. [10] in fruits of another Cucurbitaceae, Citrullus lanatus (8.8 mg of GAE/100 g sample). 


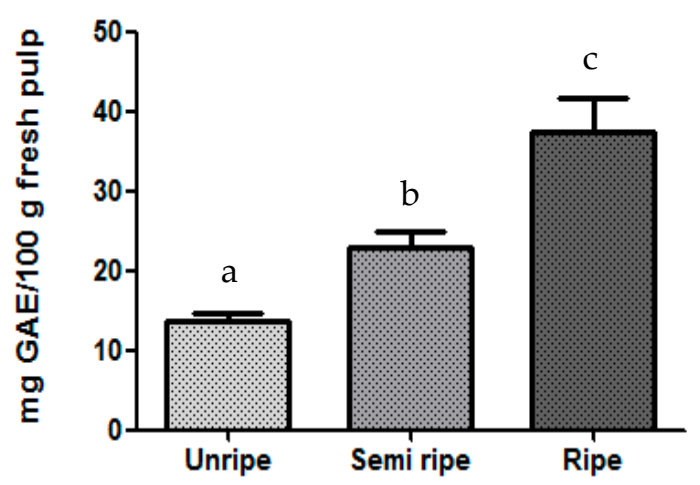

Figure 1. Total phenols content in unripe, semi-ripe and ripe Sicana odorifera fruit pulp. The bars represent the mean $\pm S D(n=3)$. Different letters on the bars indicate significant differences between the means (ANOVA, Tukey's test a posteriori, $p \leq 0.05$ ).

The content of anthocyanins was higher $(2.64 \pm 0.10 \mathrm{mg} / 100 \mathrm{~g})$ in the unripe fruit (Table 3), compared to the semi-ripe fruit $(1.55 \pm 0.70 \mathrm{mg} / 100 \mathrm{~g}$ ) or ripe (not detectable); this behavior was contrary to what was observed in the content of total phenols, whose content increased with maturity (Figure 1). This could be due to the fact that the anthocyanins are stable at acid $\mathrm{pH}$ and the $\mathrm{pH}$ in the fruit of Sicana odorifera increased with maturity (Table 2). Anthocyanins are natural compounds present in a wide variety of plants, fruits and vegetables that are of great interest to the food industry, due to their qualities as colorants (given their range of colors from red to blue) and their antioxidant properties normally due to the presence of phenols in its structure. Although for S. odorifera no values of anthocyanins are reported, the content in other cucurbits such as watermelon is lower $(0.4 \mathrm{mg} / 100 \mathrm{~g})$ than observed in this work [10].

Regarding the vitamin C content, it was observed that it was higher in the ripe pulp $(21.8 \pm 4.7$ $\mathrm{mg} / 100 \mathrm{~g}$ ) compared to the previous maturity stages. This result is higher than the value reported in pulp of $S$. odorifera harvested in Colombia $(16.0 \mathrm{mg} / 100 \mathrm{~g})$ reported by Contreras et al. [9] and Brazil $(3.21 \mathrm{mg} / 100 \mathrm{~g})$ reported by de Paula Filho et al. [3].

Table 3. Anthocyanins, vitamin C content and total antioxidant capacity (ABTS) in three stages of maturity in Sicana odorifera fruit pulp.

\begin{tabular}{cccc}
\hline \multirow{2}{*}{ Parameter } & \multicolumn{2}{c}{ Pulp } \\
\cline { 2 - 4 } & Unripe & Semi-Ripe & Ripe \\
\hline Monomeric anthocyanins $(\mathrm{mg} / 100 \mathrm{~g}$ of cyanide nidin 3-glucoside) & $2.64 \pm 0.10^{\mathrm{a}}$ & $1.55 \pm 0.70^{\mathrm{a}}$ & $*$ \\
Vitamin C $(\mathrm{mg} / 100 \mathrm{~g})$ & $<14.30$ & $<14.30$ & $21.8 \pm 4.7$ \\
Total antioxidant capacity ABTS $(\mu \mathrm{M}$ TEAC/g FW $)$ & $3.18 \pm 0.39$ & $6.75 \pm 0.90$ & $4.54 \pm 0.24$ \\
\hline
\end{tabular}

The values are means \pm SD. Different letters indicate significant differences between means (ANOVA and Tukey's test a posteriori, $p \leq 0.05)$.

In the total antioxidant capacity determination by the ABTS method (Table 3), the behavior was different; the semi-ripe fruit (normally used as a vegetable in soups) presented a statistically higher value $(6.75 \pm 0.90 \mu \mathrm{M} \mathrm{TEAC} / \mathrm{g})$ in comparison with the values of unripe and ripe fruit (3.18 \pm 0.39 and $4.54 \pm 0.24 \mu \mathrm{M} \mathrm{TEAC/g}$, respectively). The value observed in semi-ripe fruit is consistent with the value reported by Contreras et al. (2011) in ripe fruit $(6.49 \pm 0.47 \mu \mathrm{M} \mathrm{TEAC/g})$ [9], although it is expected that there are differences between the chemical concentrations of fruits compared, due to the genetic variability in some criollo varieties of Cucurbitaceae. In the seeds and skin of the fruit, high contents of total phenols were observed (Table 4), and the total antioxidant capacity was higher (18-19 $\mu \mathrm{mol}$ of Trolox/100 $\mathrm{g}$ of ripe fruit peel). 
Table 4. Total phenols content and total antioxidant capacity (ABTS) in Sicana odorifera fruits seeds and peel.

\begin{tabular}{ccccc}
\hline \multirow{2}{*}{ Variable } & \multicolumn{2}{c}{ Seeds } & \multicolumn{2}{c}{ Peel } \\
\cline { 2 - 5 } & Unripe & Ripe & Unripe & Ripe \\
\hline Total phenols $(m g$ GAE/100g FW) & $66.9 \pm 11.6^{\mathrm{a}}$ & $206 \pm 27^{\mathrm{c}}$ & $80.7^{\mathrm{a}} \pm 2.9^{\mathrm{a}}$ & $1689 \pm 7^{\mathrm{d}}$ \\
Total antioxidant capacity ABTS $(\mu \mathrm{M}$ TEAC/g FW) & $4.44 \pm 0.37^{\mathrm{a}}$ & $18.4 \pm 1.6^{\mathrm{b}}$ & $12.2^{\mathrm{a}} \pm 1.5^{\mathrm{c}}$ & $19.1 \pm 0.3^{\mathrm{b}}$ \\
\hline
\end{tabular}

The values are means \pm SD. Different letters indicate significant differences between means (ANOVA and Tukey's a posteriori test, $p \leq 0.05)$.

\section{Conclusions}

The Sicana odorifera fruits analyzed present an antioxidant potential of interest for the food industry, especially in its ripe and semi-ripe state, where the highest content of vitamin $C$ and total phenols was observed, as well as the total antioxidant capacity (ABTS). This fruit can contribute to the supply of vitamin $C$ in the diet in its fresh state and reduce the food insecurity of the population.

This work contributes to the scientific basis on the antioxidant potential of S. odorifera grown in Paraguay and opens a path towards the revaluation of the fruit. Continuing studies on its potential as a coloring and flavoring in the replacement of critical ingredients in foods, such as artificial additives, is a viable alternative based on its composition.

Acknowledgments: This work was supported by grant Ia ValSe-Food-CYTED (119RT0567). The authors are especially grateful to the "Kurugua poty" Foundation for the provision of the samples and the Facultad de Ciencias Químicas de la Universidad Nacional de Asunción for providing their facilities.

\section{References}

1. IICA. Protocolos Estandarizados para la Valoración de Frutos Nativos del Procisur Frente a la Creciente Demanda por Ingredientes y Aditivos Especializados (Carotenoides, Antocianinas y Polifenoles); PROCISUR: Montevideo, Uruguay, 2018.

2. de Paula Filho, G.X.; Barreira, T.F.; Pinheiro, S.S.; Morais Cardoso, L.; Duarte Martino, H.S.; PinheiroSant'Ana, H.M. 'Melão croá' (Sicana sphaerica Vell.) and 'maracujina' (Sicana odorifera Naud.): Chemical composition, carotenoids, vitamins and minerals in native fruits from the Brazilian Atlantic forest. Fruits 2015, 70, 341-349, doi:10.1051/fruits/2015035.

3. Lima, J.; Silva, M.P.; Teles, S.; Silva, F.; Martins, G. Avaliação de diferentes substratos na qualidade fisiológica de sementes de melão de caroá [Sicana odorifera (Vell.) Naudim]. Rev. Bras. Plantas Med. 2010, 12, 163-167, doi:10.1590/S1516-05722010000200007.

4. Zhan, Y.Y.; Wang, J.H.; Tian, X.; Feng, S.X.; Xue, L.; Tian, L.P. Protective effects of seed melon extract on CCl4-induced hepatic fibrosis in mice. J. Ethnopharmacol. 2016, 193, 531-537, doi:10.1016/j.jep.2016.10.006.

5. Mereles, L.; Ferro, E. Physical characrteristics, composition and minerals content in Macadamia integrifolia Maiden \& Betche nuts, harvested in Cordillera Department, Paraguay. Rojasiana 2015, 14, 55-68.

6. Horwitz, W. (Ed.) Official Methods of Analysis of AOAC International, 17th ed.; AOAC International: Gaithersburg, MD, USA, 2000.

7. Singleton, V.L.; Rossi, J.A. Colorimetry of Total Phenolics with Phosphomolybdic-Phosphotungstic Acid Reagents. Am. J. Enol. Vitic. 1965, 16, 144-158. doi:10.12691/ijebb-2-1-5.

8. Re, R.; Pellegrini, N.; Proteggente, A.; Pannala, A.; Yang, M.; Rice-Evans, C. Antioxidant Activity Applying an Improved Abts Radical. Free Radic. Biol. Med. 1999, 26, 1231-1237, doi:10.1016/S0891-5849(98)00315-3.

9. Contreras, J.; Calderón, L.; Guerra, E.; García, B. Antioxidant capacity, phenolic content and vitamin C in pulp, peel and seed from 24 exotic fruits from Colombia. Food Res. Int. 2011, 44, 2047-2053, doi:10.1016/j.foodres.2010.11.003.

10. Marquez, L.; Torres, F.; Pretell, C. Antocianinas totales, fenoles totales y actividad antioxidante en pulpas de frutas Total anthocyanins and phenols and antioxidant activity in fruit pulps. Pueblo Cont. 2007, 18, 209-214. 